\title{
The Dimension and Influence of Blue Ocean Leadership in Different Perspectives in Malaysia: A Systematic Review of the Literature
}

Oh Zi Jian, Khoo Yin Yin, and Marinah Awang

To Link this Article: http://dx.doi.org/10.6007/IJARBSS/v10-i12/8405

DOI:10.6007/IJARBSS/v10-i12/8405

Received: 12 October 2020, Revised: 16 November 2020, Accepted: 29 November 2020

Published Online: 17 December 2020

In-Text Citation: (Jian et al., 2020)

To Cite this Article: Jian, O. Z., Yin, K. Y., \& Awang, M. (2020). The Dimension and Influence of Blue Ocean Leadership in Different Perspectives in Malaysia: A Systematic Review of the Literature. International Journal of Academic Research in Business and Social Sciences, 10(12), 1293-1304.

Copyright: () 2020 The Author(s)

Published by Human Resource Management Academic Research Society (www.hrmars.com)

This article is published under the Creative Commons Attribution (CC BY 4.0) license. Anyone may reproduce, distribute, translate and create derivative works of this article (for both commercial and non-commercial purposes), subject to full attribution to the original publication and authors. The full terms of this license may be seen at: http://creativecommons.org/licences/by/4.0/legalcode

Vol. 10, No. 12, 2020, Pg. 1293 - 1304

Full Terms \& Conditions of access and use can be found at http://hrmars.com/index.php/pages/detail/publication-ethics 


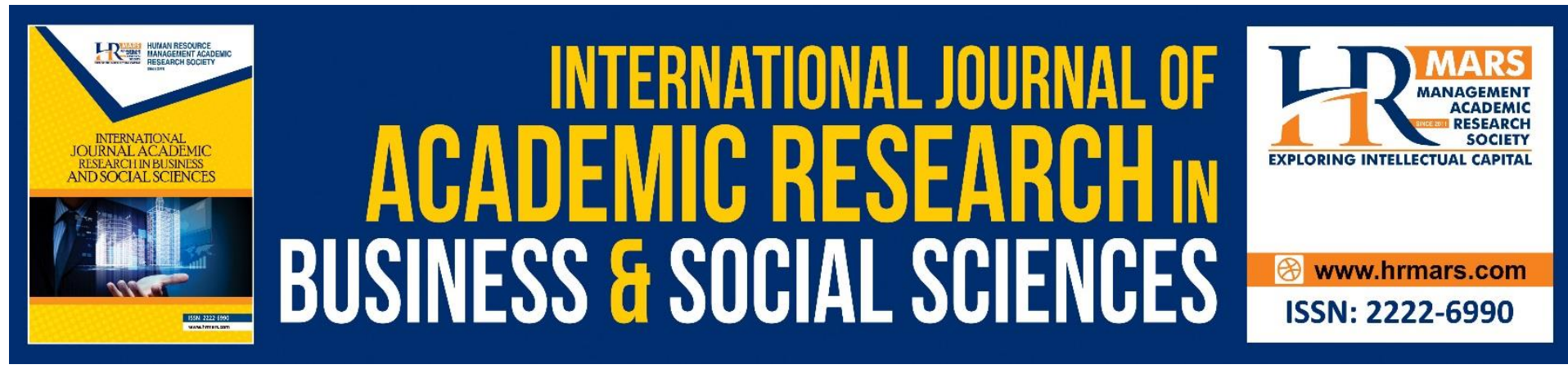

\title{
The Dimension and Influence of Blue Ocean Leadership in Different Perspectives in Malaysia: A Systematic Review of the Literature
}

\author{
Oh Zi Jian ${ }^{1}$, Khoo Yin Yin², and Marinah Awang ${ }^{3}$ \\ 1,3 Department of Educational Management, Faculty of Management and Economics, Sultan Idris \\ Education University, 35900 Tanjung Malim, Perak, Malaysia, ${ }^{2}$ Department of Economics, Faculty \\ of Management and Economics, Sultan Idris Education University, 35900 Tanjung Malim, Perak, \\ Malaysia \\ Email: ohzijian@gmail.com
}

\begin{abstract}
Blue ocean leadership is a contributing influence on organization operations from time to time. Much of the attention adjacent blue ocean leadership has aimed the different perspectives in an organization. In order to evaluate the variable of blue ocean leadership, its dimension needs to be identified. However, a lack of systematic reviews has been conducted on Malaysia's practitioner's dimension and influences (leader). Therefore, the aim of this article is to analyze the prevailing literature on Malaysian leaders related to the dimension and influence of Blue Ocean Leadership. A systematic review of Scopus, Google Scholar, and other resource databases, driven by the PRISMA Statement (Preferred Reporting Items for Systematic Reviews and Meta-Analyses) review process, resulted in an established 10 related studies. Advance review of these articles occasioned in several main perspectives - employee engagement, strategic decision making, organizational politics, firm performance, and emotional intelligence. This paper will be served as a guidance for the implementation of BOL in other organizational context.
\end{abstract}

Keywords: Blue Ocean Leadership, Employee Engagement, Strategic Decision Making, Organizational Politics, Firm Performance, Emotional Intelligence, Systematic Literature Review

\section{Introduction}

There has been tremendous interest in leadership research in the twenty-first century. In recent years, leadership has been mainly revised in academia, research, and industrial societies' executive communities (Kouhdasht, Mahdian \& Naeini, 2013). Leaders are also practicing different leadership styles in the organization (Oshagbemi \& Ocholi, 2006). Since leadership styles and practices have contributed to the success and failure of the organization in recent times (Lok \& Crawford, 2004), a new type of leadership model known as the Blue Ocean Leadership (BOL) style that was devised by Kim and Mauborgne (2014) emerged.

BOL is a modern leadership style introduced by Kim and Mauborgne (2014). This leadership style benefits the company by improving the organizational leadership profile by engaging the previously disengaged employee. BOL focuses on achieving organizational development rapidly and at low cost, it also improves leadership strength, which could be turned into higher productivity for the 
company (Kim \& Mauborgne, 2014). From the perspective of BOL, every leader has a customer. Therefore, the underlying principle is that leadership can be seen as a commodity that people buy 'or don't buy 'in an organization's management.

In addition, Kim and Mauborgne (2014) explained BOL as an efficient and organized way to cultivate leadership skills that maximize the current untouched talent and intellectual capital resources towards organizational effectiveness. This can be applied by seeking input from employees to reflect on leadership activities. Leadership practices are explained at this juncture as actions and behaviors in which leaders dedicate their time, money, and effort to manage an organization. In addition to this, employees will feel involved as their input is taken into account in creating new leadership profiles at various leadership levels for organizational change (Zakaria, Idris \& Ismail, 2017).

BOL's practice emphasizes leaders' act and activities rather than conventional leadership approaches that pay attention to leader values, traits, styles, and behavior. It will immediately impact organizational change by altering leaders' actions and activities, as employees do not believe that their leader will suddenly change characters and personality. In the meantime, at low cost, debauched implementation, and capable of producing exceptional impact performance, this approach can be instigated.

Although, several previous studies have acknowledged BOL to some degree (Kim \& Mauborgne, 2014; Wan Hanafi, Daud \& Baharin, 2016; Zakaria, Idris \& Ismail, 2017; Wan Hanafi \& Daud, 2019), there are still many literatures that still not shared consensus between them on the dimension that should be used to measure BOL. While extensive research has been carried out on $\mathrm{BOL}$, current studies seem to miss some of the essential points that may help provide an accurate and detailed understanding of BOL's influence in different perspectives, especially in the context of Malaysia. Therefore, for the reader to better understand it, there is a need to conduct a Systematic Literature Review (SLR) on this topic. The objective of this paper is to review the dimension and influence of blue ocean leadership in different perspectives in Malaysia by using SLR.

\section{Review Question}

This systematic literature review performed to address the following questions:

(a) What is the dimension of BOL?

(b) What is the influence of BOL in different perspectives in Malaysia?

\section{Methodology}

The method employed to repossess articles related to BOL's dimension and influence in various perspectives in Malaysia is discussed in this section. The PRISMA method is employed to prevent the literature review is not biased in the reporting process (Liberati et al., 2009). This approach comprised resources (Scopus, Google Scholar, and Dimensions) used to conduct the systematic review, eligibility and exclusion requirements, review process steps (identification, screening, eligibility), and abstraction and analysis of data.

The eligibility in this review was controlled by the researcher to (a) only research articles and conference proceedings with empirical data chosen or related concept paper; (b) articles must be published in the English language to prevent any misunderstanding and difficulty in translation; (c) only articles dated published between 2014 and 2020 were selected; (d) the chosen articles are indexed social sciences citation index articles only; and (e) articles are from Malaysia. The exclusion criteria including; (a) non-indexed journals, book, chapter in books, magazine, thesis, and dissertations; (b) Non-English journals; (c) articles dated published before 2014; (d) articles are science citation indexed articles and (e) journals that not from Malaysia. All these eligibility and exclusions are summarised in Table 1. 
Table 1. Inclusion and Exclusion Criteria

\begin{tabular}{|l|l|l|}
\hline Criterion & Eligibility & Exclusion \\
\hline Literature type & $\begin{array}{l}\text { Indexed Journal (research } \\
\text { articles, conference } \\
\text { proceedings, concept paper) }\end{array}$ & $\begin{array}{l}\text { Non-indexed journals, book, chapter } \\
\text { in book, magazine, thesis, and } \\
\text { dissertations }\end{array}$ \\
\hline Language & English & Non-English \\
\hline Timeline & Between 2014-2020 & $<2014$ \\
\hline Indexes & Social Science Citation Index & Science Citation Indexed Expanded \\
\hline Country & Malaysia & Non-Malaysia \\
\hline
\end{tabular}

In November 2020, the systematic literature review process was performed in four phases. The first stage consists of the creation of identical keyword strings and the abstraction of articles in the chosen databases. These strings are linked to the leadership of the blue oceans shown in Table 2. The findings showed 45 articles collected from the selected databases. Next, we removed 12 duplicated articles. The remaining 33 articles were examined for their field of study as we performed our systematic literature review only in the organization's context. At this stage, 20 articles were removed as it is not discussed $\mathrm{BOL}$ in the organizational setting. Eligibility and exclusion for the remaining 13 papers are carried out during the third stage. At this stage, we conducted a thorough analysis of the remaining articles. The articles that not focused on the research questions of this paper were removed. A total of 10 papers went through to the final stage, which is the qualitative analysis. Figure 1 demonstrates the procedures for this analysis.

Table 2. The Search String Used For The Systematic Review Process

\begin{tabular}{|l|l|}
\hline Databases & Keywords Used \\
\hline Scopus & TITLE-ABS-KEY ("blue ocean leadership" OR "blue ocean strategy in \\
& leadership") AND ( LIMIT-TO (DOCTYPE, "ar") OR LIMIT- \\
& TO ( DOCTYPE, "cp") OR LIMIT-TO (DOCTYPE, "re" )) AND ( LIMIT \\
& TO ( LANGUAGE, "English")) AND ( LIMIT-TO (PUBYEAR, 2019) OR LIMIT- \\
& $\begin{array}{l}\text { TO ( PUBYEAR, 2018) OR LIMIT-TO (PUBYEAR, 2017) OR LIMIT- } \\
\text { TO ( PUBYEAR, 2016) OR LIMIT-TO (PUBYEAR, 2014 )) }\end{array}$ \\
\hline $\begin{array}{l}\text { Google } \\
\text { Scholar }\end{array}$ & allintitle: ("blue ocean leadership" OR "blue ocean strategy in leadership") \\
\hline Dimensions & ("blue ocean leadership" OR "blue ocean strategy in leadership") \\
\hline
\end{tabular}

\section{Results and Discussion}

Scholarly works listed the results of these 10 papers in this section. Based on these 10 articles', 7 articles used quantitative methods (research paper), and three studies using analyzing literature review methods (concept paper). The majority of the research used quantitative methods in data collection from this finding. However, the use of analyzed literature review method can also be used to study the concept.

$\mathrm{BOL}$ can be explained in several dimensions. In comparison, the influence of $\mathrm{BOL}$ can be categorized in three perspectives: (1) employee engagement, (2) strategic decision making, organizational politic and emotional intelligence, and (3) lean manufacturing and firm performance.

\section{Discussion}

\section{Dimension of BOL}

The previous researcher suggested several dimension of BOL. The study of Wan Hanafi, Daud 
and Baharin (2016) suggested traits as one of the BOL dimension, which is including eliminate, raise, reduce, and create. They use the Multifactor Leadership Questionnaire (MLQ from 5x) to measure BOL. Next, the study of Wan Hanafi, Daud, Islam, Bahrin, Ramli, and Isa (2017) identified BOL attributes at Governments Linked Companies (GLCs) and Multi-National Companies (MNCs), namely visionary, contingent reward, courage, idealized influence, inspiration, intellectual stimulation, passion, strategic thinking/planner, focus, collaborate, innovate, willingness to change and communication. Meanwhile, Oh, Khoo and Awang (2020) clarified three dimension of BOL at five colleges at Penang, Malaysia, which is focus, visionary and idealized influences. Whereas Jian, Yin and Awang (2020) validate the dimension from the study of Oh et. al., (2020) in 22 Vocational Colleges in the North Zone of Malaysia and found that it achieved construct validity and reliability. In this review, only four studies mentioned the dimension of BOL in Malaysia.

\section{The Influence of BOL}

\section{Employee Engagement}

Zakaria et al. (2017) take the first step to illustrate how BOL practices can enhance employee engagement in Malaysia's public service as employee engagement is a critical issue worldwide. They explained that BOL offers new frameworks and tools for public service leaders to increase employee engagement levels. Hence, this new leadership profile emerged on leadership canvas and is collective by employees who aim to inspire them to endeavour the organization performance. In the same year, Wan Hanafi et al. (2017) had conducted a study to examine the relationship of BOL attributes towards employee engagement. Surprisingly, the results is in line with Zakaria et al. (2017). It exhibited that all the BOL attributes would positively influence employee engagement, except idealized influence, passion, strategic thinking/planner, innovate, and willingness to change. 

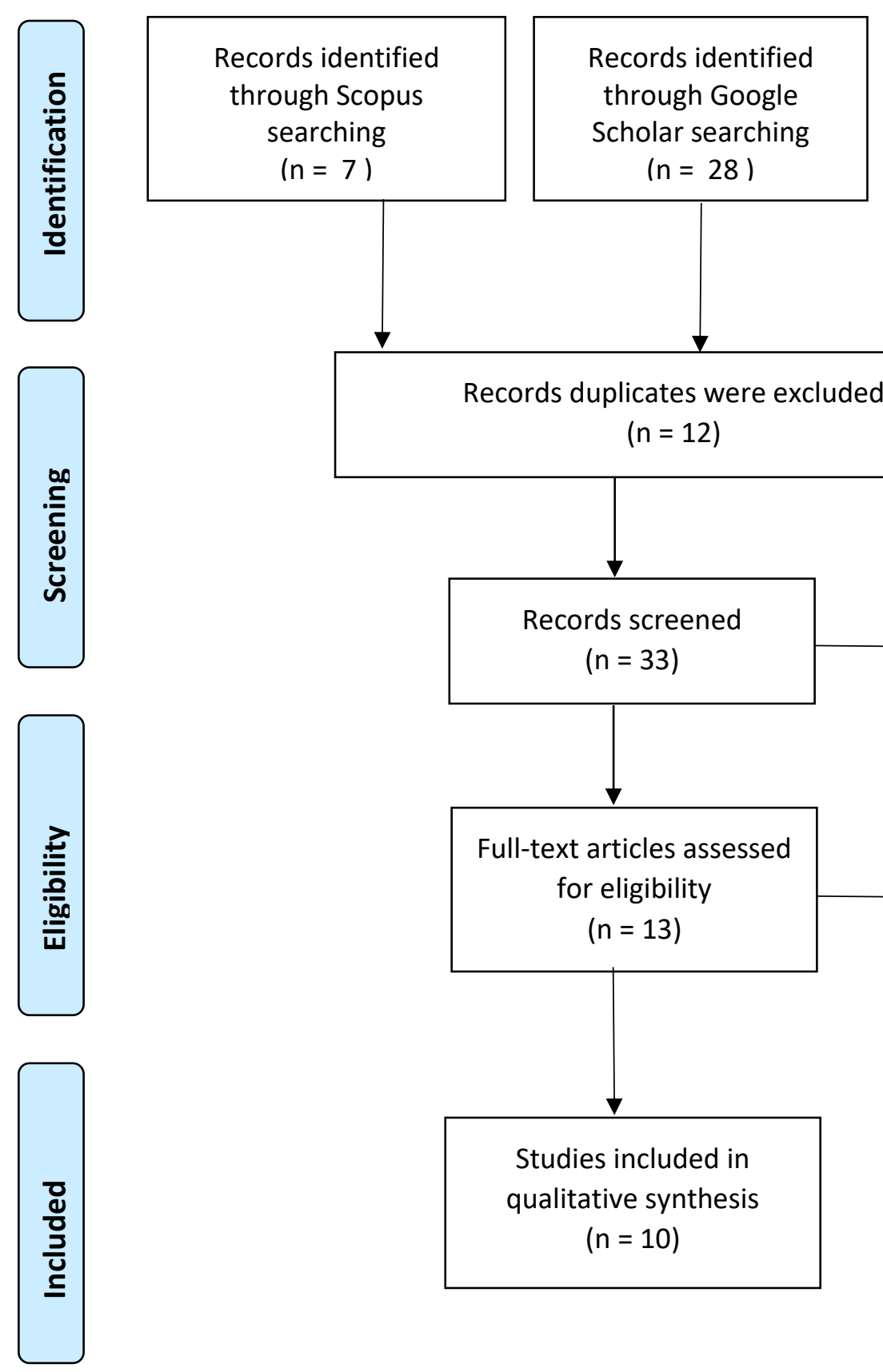

$(n=28)$
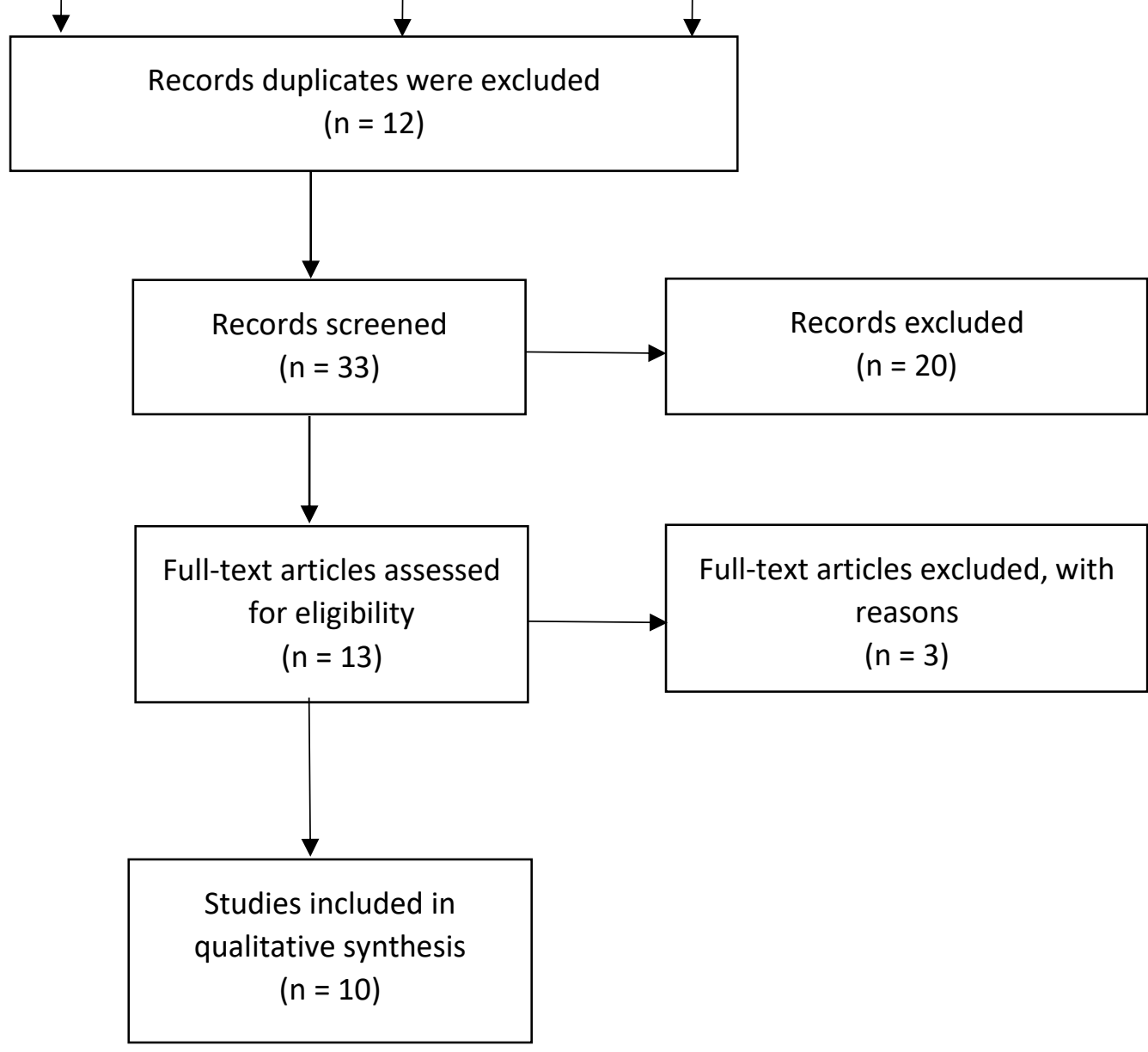

Figure 1. A flow diagram detailing the application of PRISMA to the qualitative synthesis on the dimension and influence of Blue Ocean Leadership in different perspectives before November 2020.

\section{Emotional Intelligence, Strategic Decision Making, and Organizational Politic}

The study of Wan Hanafi, Daud, and Baharin (2018) attempts to observe the influences of BOL styles on emotional intelligence among middle to top-level leaders from the selected government link companies (GLCS), which is listed in the Government Link Transformation Programme (GLTP). The finding showed that the style of blue ocean leadership and emotional intelligence have a significant relationship. Subsequently, Daud and Wan Hanafi (2018) continue to examine the influences of BOL style on strategic decision-making moderates by emotional intelligence. The findings showed that the relationship between $\mathrm{BOL}$ and strategic decision making moderated by emotional intelligence. Nevertheless, this study never stops exploring and further investigate by Wan Hanafi and Daud (2019). 
They extend the previous research to examine BOL's effect on strategic decision-making mediating by organizational politics. The result suggested that organizational politics had a partial mediating impact on the relationship between BOL styles and strategic decision-making.

\section{Lean Manufacturing and Firm Performance}

Loh, Mohd Yusof, and Lau (2019) take their initiative to introduce the BOL concept to address many companies' failure to lean implementation or unsustainable lean for a long time. Loh and his friends stressed the idea of BOL focuses on the acts and activities of leaders, which can be modified with less effort and time. At the same time, seven categories of lean activities for leaders are identified which is (1) visionary and forward-thinking, (2) self-development, (3) continuous improvement (Kaizen), (4) Genchi Genbutsu (go and see/genba), (5) empower and coaching oriented, (6) two-way effective communication, and (7) motivation. Furthermore, Loh and Mohd Yusof (2019) extend their research to analyze the mediation effect of $\mathrm{BOL}$ activities between lean manufacturing (LM) practices and firm performance. The findings of their study exhibited that LM practices have a positive and significant effect on firm performance. Genba-Kaizen activities have greatly increased the firm performance by an impressive 30 percent.

\section{Conclusion}

This systematic literature review's primary purposes are to briefly view BOL's dimension and influence in Malaysia's different perspective. In this review, the researcher found that BOL's leading dimension has been suggested: visionary, contingent reward, courage, idealized influence, inspiration, intellectual stimulation, passion, strategic thinking/ planner, focus, collaborate, innovate, willingness to change, and communication. In the meantime, BOL influence employee engagement, emotional intelligence, strategic decision making, organizational politic, lean manufacturing, and firm performance. However, this review is only limited to the organizational context. The results can be a great reference to identify the research gaps in BOL's dimension and influence in Malaysia's different perspectives. For the further systematic literature review, the researcher recommends further reviewing BOL's dimension, and related variables as the new paper on BOL might continuously publish in the future. Hence, BOL's more dimension and associated variables will be explored in detail; BOL's more accurate findings will succeed to be collected. By doing this, it will ease the procedure of the researcher when developing the instrument. Besides, the researcher may focus on the challenges of implementing BOL in another country's organizational context.

\section{Acknowledgment}

Acknowledgement to my supervisor, co-supervisor, and friends who have guided me in writing this article.

\section{Corresponding Author}

Oh Zi Jian, Faculty of Management and Economics, Sultan Idris Education University, Perak, Malaysia

Email: ohzijian@gmail.com 
INTERNATIONAL JOURNAL OF ACADEMIC RESEARCH IN BUSINESS AND SOCIAL SCIENCES

Vol. 10, No. 12, 2020, E-ISSN: 2222-6990 @ 2020 HRMARS

Table 3. The systematic literature review table of findings.

\begin{tabular}{|c|c|c|c|c|c|c|c|c|}
\hline No. & $\begin{array}{l}\text { Authors and } \\
\text { date }\end{array}$ & Country & $\begin{array}{l}\text { Types of } \\
\text { Paper }\end{array}$ & Design & Sample & Analyze & Purpose/Objectives & Findings \\
\hline 1 & $\begin{array}{l}\text { Wan Hanafi } \\
\text { \& Daud } \\
\text { (2019) }\end{array}$ & Malaysia & $\begin{array}{l}\text { Research } \\
\text { Paper }\end{array}$ & $\begin{array}{l}\text { Quantitative } \\
\text { study } \\
\text { (Questionnaire) }\end{array}$ & $\begin{array}{l}\text { Middle to the top- } \\
\text { level manager in } \\
\text { the Malaysian } 20 \\
\text { largest Government } \\
\text { Link Companies } \\
\text { (GLCs): } 329 \text { people }\end{array}$ & $\begin{array}{l}\text { Partial Least } \\
\text { Square Structural } \\
\text { Equation Model } \\
\text { (PLS-SEM) }\end{array}$ & $\begin{array}{l}\text { To examine the effect of } \\
\text { blue ocean leadership style } \\
\text { on strategic decision } \\
\text { making mediates by } \\
\text { organizational politic. }\end{array}$ & $\begin{array}{l}\text { There is a partial mediating } \\
\text { effect of organizational } \\
\text { politics on the relationship of } \\
\text { blue ocean leadership styles } \\
\text { and strategic decision } \\
\text { making. }\end{array}$ \\
\hline 2 & $\begin{array}{l}\text { Loh, Mohd } \\
\text { Yusof \& Lau } \\
\text { (2019) }\end{array}$ & Malaysia & $\begin{array}{l}\text { Concept } \\
\text { Paper }\end{array}$ & $\begin{array}{l}\text { Analyze } \\
\text { Literature } \\
\text { Review }\end{array}$ & - & $\begin{array}{l}\text { Analyze } \\
\text { Literature } \\
\text { Review }\end{array}$ & $\begin{array}{l}\text { To introduce the Blue } \\
\text { Ocean Leadership concept } \\
\text { to address the issue of } \\
\text { many companies fail lean } \\
\text { implementation or is not } \\
\text { able to sustain lean } \\
\text { for a long time. }\end{array}$ & $\begin{array}{l}\text { The Blue Ocean Leadership } \\
\text { concept focuses on leaders' } \\
\text { acts and activities, which can } \\
\text { be changed with less effort } \\
\text { and time. Seven categories of } \\
\text { lean activities for leaders are } \\
\text { identified, which is } \\
\text { a) Visionary and forward- } \\
\text { thinking } \\
\text { b) Self-development } \\
\text { c) Continuous improvement } \\
\text { (Kaizen) } \\
\text { d) Genchi Genbutsu (go and } \\
\text { see/genba) } \\
\text { e) Empower and coaching } \\
\text { oriented } \\
\text { f) Two-way effective } \\
\text { communication } \\
\text { g) Motivation }\end{array}$ \\
\hline 3 & $\begin{array}{l}\text { Loh \& Mohd } \\
\text { Yusof } \\
\text { (2019) }\end{array}$ & Malaysia & $\begin{array}{l}\text { Research } \\
\text { Paper }\end{array}$ & $\begin{array}{l}\text { Quantitative } \\
\text { study } \\
\text { (Questionnaire) }\end{array}$ & $\begin{array}{l}\text { Three significant } \\
\text { automotive vendor } \\
\text { associations in }\end{array}$ & $\begin{array}{l}\text { Smart PLS3.0 } \\
\text { SEM }\end{array}$ & $\begin{array}{l}\text { To investigate the } \\
\text { mediation effect of Blue } \\
\text { Ocean Leadership (BOL) }\end{array}$ & $\begin{array}{l}\text { LM practices have a positive } \\
\text { and significant impact on firm } \\
\text { performance. Activities of }\end{array}$ \\
\hline
\end{tabular}




\section{Malaysia: Proton}

Vendor Association

(PVA), Kelab

Vendor Perodua

(KVP) and Toyota

Supplier Club (TSC):

64 people

4 Wan Hanafi, Malaysia Research Quantitative

Daud, Islam,

Bahrin,

Ramli \& Isa

(2017)

\section{Paper study}

(Questionnaire)
Manager and above

positions at few

Governments

Linked Companies

(GLCs) and Multi-

National

Companies (MNCs):

329 people activities between lean

manufacturing (LM)

practices and firm

performance

Partial Least

Square Structural leadership attributes those

Equation Model were practiced in the

(PLS-SEM)

organization and examine

the relationship

towards employee

engagement.
Genba-Kaizen significantly improve the firm

performance by an astonishing 30 percent.

Blue ocean leadership attributes are identified, which is
a) Visionary
b) Contingent reward
c) Courage
d) Idealized influence

e) Inspiration

f) Intellectual stimulation

g) Passion

h) Strategic thinking/ planner

i) Focus

j) Collaborate

k) Innovate

l) Willingness to change

m) Communication

All the blue ocean leadership attributes would positively influence employee engagement, except idealized influence, passion, strategic thinking/planner, innovate, and willingness to change. 
INTERNATIONAL JOURNAL OF ACADEMIC RESEARCH IN BUSINESS AND SOCIAL SCIENCES

Table 3. Continued

\begin{tabular}{|c|c|c|c|c|c|c|c|c|}
\hline No. & $\begin{array}{l}\text { Authors and } \\
\text { date }\end{array}$ & Country & $\begin{array}{l}\text { Types of } \\
\text { Paper }\end{array}$ & Design & Sample & Analyze & Purpose/Objectives & Findings \\
\hline 5 & $\begin{array}{l}\text { Wan Hanafi, } \\
\text { Daud \& } \\
\text { Baharin } \\
(2016)\end{array}$ & Malaysia & $\begin{array}{l}\text { Concept } \\
\text { Paper }\end{array}$ & $\begin{array}{l}\text { Analyze } \\
\text { Literature } \\
\text { Review }\end{array}$ & - & $\begin{array}{l}\text { Analyze } \\
\text { Literature } \\
\text { Review }\end{array}$ & $\begin{array}{l}\text { To review past research and } \\
\text { identify whether the } \\
\text { "Multifactor Leadership } \\
\text { Questionnaire" (MLQ From } \\
5 x \text { ) is applicable to measure } \\
\text { blue ocean leadership } \\
\text { traits. }\end{array}$ & $\begin{array}{l}\text { MLQ has been improved by } \\
\text { including Blue ocean } \\
\text { leadership traits, which is } \\
\text { a) Eliminate } \\
\text { b) Raise } \\
\text { c) Reduce } \\
\text { d) Create }\end{array}$ \\
\hline 6 & $\begin{array}{l}\text { Zakaria, Idris } \\
\& \text { Ismail } \\
\text { (2017) }\end{array}$ & Malaysia & $\begin{array}{l}\text { Concept } \\
\text { Paper }\end{array}$ & - & - & - & $\begin{array}{l}\text { To explain how Blue Ocean } \\
\text { Leadership (BOL) practices } \\
\text { can enhancing employee } \\
\text { engagement in public } \\
\text { service in Malaysia }\end{array}$ & $\begin{array}{l}\text { Blue Ocean Leadership offers } \\
\text { a new framework and tools } \\
\text { for leaders in public service } \\
\text { to increase employee } \\
\text { engagement levels. Finally, } \\
\text { this new leadership profile is } \\
\text { shown on a leadership } \\
\text { canvas and shared among } \\
\text { employees that aim to } \\
\text { motivate them to strive for } \\
\text { organizational excellence. }\end{array}$ \\
\hline 7 & $\begin{array}{l}\text { Daud \& Wan } \\
\text { Hanafi } \\
(2018)\end{array}$ & Malaysia & $\begin{array}{l}\text { Research } \\
\text { Paper }\end{array}$ & $\begin{array}{l}\text { Quantitative } \\
\text { study } \\
\text { (Questionnaire) }\end{array}$ & $\begin{array}{l}\text { Middle to top-level } \\
\text { leaders from } \\
\text { selected } \\
\text { government link } \\
\text { companies (GLCs): } \\
757 \text { people }\end{array}$ & $\begin{array}{l}\text { Partial least } \\
\text { square structural } \\
\text { (PLS-SEM) }\end{array}$ & $\begin{array}{l}\text { To examine the influences } \\
\text { of blue ocean leadership } \\
\text { style on strategic decision- } \\
\text { making moderates by } \\
\text { emotional intelligence. }\end{array}$ & $\begin{array}{l}\text { Emotional intelligence } \\
\text { moderates the relationship } \\
\text { between } \\
\text { blue ocean leadership and } \\
\text { strategic decision making }\end{array}$ \\
\hline 8 & $\begin{array}{l}\text { Oh, Khoo \& } \\
\text { Awang } \\
(2020) \\
\end{array}$ & Malaysia & $\begin{array}{l}\text { Research } \\
\text { Paper }\end{array}$ & $\begin{array}{l}\text { Quantitative } \\
\text { study } \\
\text { (Questionnaire) }\end{array}$ & $\begin{array}{l}\text { Lecturers from five } \\
\text { vocational colleges }\end{array}$ & $\begin{array}{l}\text { Exploratory } \\
\text { Factor Analysis } \\
\text { (EFA) }\end{array}$ & $\begin{array}{l}\text { To clarify how to gain } \\
\text { validity and reliability of the }\end{array}$ & $\begin{array}{l}\text { Thirteen (13) items comply } \\
\text { with three ( } 3 \text { ) aspects, i.e., } \\
\text { focus ( } 7 \text { items), visionary ( } 3\end{array}$ \\
\hline
\end{tabular}


INTERNATIONAL JOURNAL OF ACADEMIC RESEARCH IN BUSINESS AND SOCIAL SCIENCES

\section{in Penang, \\ Malaysia:}

300 people

9 Wan Hanafi, Malaysia

Daud \&

Baharin

(2018)

10 Jian, Yin \&

Awang

(2020)

\section{Research}

Paper

Quantitative
study

study

(Questionnaire)

\section{Middle to top-level} leaders from the

selected

government link

companies (GLCs)

which is listed in

the Government

Link Transformation

Programme (GLTP)

120 people

Lecturers from 22

vocational colleges

in the North Zone

of Malaysia, which

is Penang, Kedah,

Perlis, and Perak:

401 people questionnaire's items by

using the EFA

process for measurement of the $\mathrm{BOL}$ construct

Partial least

square structura

model (PLS-SEM)

To examine the influences

of blue ocean leadership

styles on emotional

intelligence.

\section{Confirmatory \\ Factor Analysis \\ (CFA)}

To validate the research

instrument measuring blue

ocean leadership. items), and idealized

influences ( 3 items)

concluded in the study.

There is a significant relationship between blue ocean leadership style and emotional intelligence
The measurement model of the Blue Ocean Leadership construct achieved the requirement for construct validity and reliability and ought to be proficient to be applied by other researchers. 


\section{References}

Daud, S., \& Wan Hanafi, W. N. (2018). Blue ocean leadership style and strategic decision making among leaders at government link companies (GLCs): The role of emotional intelligence as moderator. Global Business and Management Research: An International Journal, 10(3), 816-827.

Jian, O. Z., Yin. K. Y., Awang, M. (2020). Validating the instruments measuring blue ocean leadership construct using confirmatory factor analysis. International Journal of Academic Research in Business and Social Sciences, 10(5), 857-868. http://dx.doi.org/10.6007/IJARBSS/v10-i5/7255

Kim, W. C., \& Mauborgne, R. (2014). Blue Ocean Leadership. Harvard Business Review, 1-12

Kouhdasht, R. N., Mahdian, M. J., \& Naeini, M. A. (2013). The relationship between emotional intelligence and thinking styles in male and female students in Tehran, Iran. International Journal of Learning \& Development, 3(3), 110-119. doi: 10.5296/ijld.v3i3.3865

Liberati, A., Altman, D. G., Tetzlaff, J., Mulrow, C., Gøtzsche, P. C., loannidis, J. P. A., ... Moher, D. (2009). The PRISMA Statement for Reporting Systematic Reviews and MetaAnalyses of Studies That Evaluate Health Care Interventions: Explanation and Elaboration. PLoS MEDICINE, 6(7). https://doi.org/10.1371/journal.pmed.1000100.

Loh, K. L., Yusof, M. S., \& Lau, D. H. C. (2019). Blue ocean leadership in lean sustainability. International Journal of Lean Six Sigma, 10(1), 275-294. https://doi.org/10.1108/IJLSS06-2016-0029

Lok, P., \& Crawford, J. D. (2004). The effect of organisational culture and leadership style on job satisfaction and organisational commitment. Journal of Management Development, 23(4), 321-338. doi: 10.1108/02621710410529785

Oh, Z. J., Khoo, Y. Y., \& Awang, M. (2020). Developing item for blue ocean leadership in vocational college. International Journal of Academic Research in Business \& Social Sciences, 10(4), 268-280. http://dx.doi.org/10.6007/IJARBSS/v10-i4/7127

Oshagbemi, T., \& Ocholi, S. A. (2006). Leadership styles and behaviour profiles of managers. Journal of Management Development, 25(8), 748-762.

doi: 10.1108/02621710610684231

Wan Hanafi, W. N., \& Daud, S. (2019). Attaining sustainable organization in an era of technology disruption through leadership and strategic decision making: Mediating role of organizational politics. International Journal of Engineering and Advanced Technology (IJEAT), 9(1), 3561-35661.

Wan Hanafi, W. N., Daud, S., \& Baharin, N. L. (2016). Is MLQ instrument applicable to verify the blue ocean leadership traits? International Conference on Advances in Renewable Energy and Technologies (ICARET 2016), pp 1-4. doi:10.1088/1755-1315/32/1/012054

Wan Hanafi, W. N., Daud, S., Baharin, N. L. (2018). Blue ocean leadership and emotional intelligence in government link companies (GLCs): Preparing for Industry 4.0. SHS Web of Conferences, 56, 1-14. https://doi.org/10.1051/shsconf/20185604008

Zakaria, Z., Idris, K., \& Ismail, M. B. (2017). Blue ocean leadership (BOL) practices towards promoting employee engagement in public service. International Journal of Academic Research in Business and Social Sciences, 7(3), 85-98. 